Treatise on Invertebrate Paleontology, Part N, Mollusca 6. Geological Society of America and University of Kansas Press, Lawrence.

Pojeta, J., JR. AND B. RunNegar. 1976. The paleontology of rostroconch mollusks and the early history of the phylum Mollusca. U.S. Geological Survey Professional Paper 968, 88 p.

RAUP, D. M. 1975. Taxonomic survivorship curves and Van Valen's Law. Paleobiology, 1:82-96.

- 1978a. Approaches to the extinction problem. Journal of Paleontology, 52:517-523.

- 1978b. Cohort analysis of generic survivorship. Paleobiology, 4:1-15.

. 1981. Extinction: bad genes or bad luck? Acta Geologica Hispanica, 16:25-33.

- 1982. Biogeographic extinction: a feasibility test, p. 277-281. In L. T. Silver and P. H. Schultz (eds.), Geological Implications of Impacts of Large Asteroids and Comets on the Earth. Geological Society of America Special Paper 190.

Russell, D. A. 1982. The mass extinctions of the late Mesozoic. Scientific American, 246:5865.

SEPKOSKI, J. J., JR. 1975. Stratigraphic biases in the analysis of taxonomic survivorship. Paleobiology, 1:343-355.
- 1978. A kinetic model of Phanerozoic taxonomic diversity I. Analysis of marine orders. Paleobiology, 4:223-251.

- 1982. Mass extinctions in the Phanerozoic oceans: a review, p. 283-289. In L. T. Silver and P. H. Schultz (eds.), Geological Implications of Impacts of Large Asteroids and Comets on the Earth. Geological Society of America Special Paper 190.

STANLEY, S. M. 1977. Trends, rates, and patterns of evolution in the Bivalvia, p. 209-250. In A. Hallam (ed.), Patterns of Evolution as Illustrated by the Fossil Record, Developments in $\mathrm{Pa}$ laeontology and Stratigraphy, 5. Elsevier Scientific Publishing Company, Amsterdam.

TAPPAN, H. 1982. Extinction or survival: selectivity and causes of Phanerozoic crises, p. 265276. In L. T. Silver and P. H. Schultz (eds.), Geological Implications of Impacts of Large Asteroids and Comets on the Earth. Geological Society of America Special Paper 190.

VAN VAlen, L. 1973. A new evolutionary law. Evolutionary Theory, 1:1-30.

WARD, P. 1983. The extinction of the ammonites. Scientific American, 249:136-147.

MANUSCRIPT RECEIVED 11 SEPTEMBER 1983

REVISED MANUSCRIPT RECEIVED 22 FEBRUARY 1984

\title{
ANNOUNCEMENT
}

\section{GEORGE GAYLORD SIMPSON PRIZE}

The Peabody Museum of Natural History, Yale University, presented the second George Gaylord Simpson Prize to Christine Janis, Division of Biology and Medicine, Brown University, for her paper "Evolution of horns in ungulates: ecology and paleoecology." $\mathrm{Bi}$ ological Review, 57:261-318, 1982. 